\title{
Metavanadate(V) Anions as Corrosion Inhibitor for Carbon Steel in Acid Chloride Solution
}

\author{
Mieczyslaw Scendo ${ }^{*}$ Joanna Trela, Katarzyna Staszewska \\ Institute of Chemistry, Jan Kochanowski University in Kielce, Swietokrzyska 15G, PL- 25406 Kielce, \\ Poland \\ *E-mail: scendo@ujk.edu.pl
}

doi: $10.20964 / 110402666$

Received: 22 December 2015 / Accepted: 26 January 2016 / Published: 1 March 2016

The influence of metavanadate $(\mathrm{V})$ anions $\left(\mathrm{VO}_{3}{ }^{-}\right)$concentration on the corrosion of $\mathrm{S} 235$ carbon steel in acid chloride solutions were studied. The investigations were involved by electrochemical polarization methods. Tafel polarization study revealed that of $\mathrm{VO}_{3}{ }^{-}$ions were acted as a mixed-type inhibitor. The inhibition efficiency increased with an increase in the concentration of metavanadate anions. The adsorption of $\mathrm{VO}_{3}{ }^{-}$has been found to occur on the surface of S235 carbon steel according to the El-Awady isotherm. The corrosion kinetic parameters of carbon steel, and adsorption thermodynamic parameters for metavanadate $(\mathrm{V})$ anions were determined and discussed.

Keywords: A. S235 carbon steel; A. Metavanadate(V) anion; C. Corrosion rate; C. Kinetic parameters; C. Thermodynamic parameters, C. El-Awady isotherm

\section{$\underline{\text { FULL TEXT }}$}

(C) 2016 The Authors. Published by ESG (www.electrochemsci.org). This article is an open access article distributed under the terms and conditions of the Creative Commons Attribution license (http://creativecommons.org/licenses/by/4.0/). 